\title{
EFFECT OF SPLIT AND FOLIAR APPLICATION OF NITROGEN ON LEAF NITROGEN CONCENTRATION, SPAD INDEX AND PHOTOSYNTHESIS IN BT. COTTON (Gossypium hirsutum L.)
}

\author{
M. D. Giri ${ }^{* 1}$, M. B. Dhonde ${ }^{2}$ and A. D. Tumbare ${ }^{2}$ \\ ${ }^{1}$ Dr. Panjabrao Deshmukh Krishi Vidyapeeth, Akola 444 104, India \\ ${ }^{2}$ Department of Agronomy, Mahatma Phule Krishi Vidyapeeth, Rahuri 413 722, India
}

\begin{abstract}
A field experiment was carried out at Rahuri (Maharashtra) India in consecutive years of 2011 to 2012 to study the response of split and foliar application of nitrogen on leaf nitrogen concentration, SPAD index and photosynthesis in Bt cotton (Gossypium hirsutum L). Ten treatments comprising nitrogen-management practices (application of recommended dose of nitrogen in 3, 4, 5, 6 splits; foliar application of 20 $\mathrm{g} \mathrm{KNO}_{3}$ litre $^{-1}$ water, $20 \mathrm{~g}$ urea litre ${ }^{-1}$ water, combination of split application of nitrogen and foliar spray of $20 \mathrm{~g} \mathrm{KNO}_{3}$ litre ${ }^{-1}$ water, $20 \mathrm{~g}$ urea litre ${ }^{-1}$ water and control) were tested on inceptisol. Results indicated that application of nitrogen in six splits $(20 \%$ at sowing as basal and remaining in 5 equal splits at $30,45,60,75$ and 90 DAS) registered significantly higher leaf nitrogen content, SPAD index and rate of photosynthesis except 60 DAS where 4 nitrogen split showed higher leaf nitrogen content and SPAD index. Similarly the same treatment registered significantly higher plant height, dry matter accumulation, number of bolls plant ${ }^{-1}$ and lint yield.
\end{abstract}

Keywords: Leaf nitrogen, SPAD, photosynthesis, lint yield, split application of nitrogen, foliar fertilization

\section{INTRODUCTION}

Cotton is the world's leading fibre crop and grown in more than 80 countries. India accounts for about $32 \%$ of the global cotton area and contributes to $21 \%$ of the global cotton, currently ranking second after China (Anonymous, 2012). The indeterminate growth habit of cotton (Gossypium hirsutum L.) dramatically affects its response to nitrogen fertilizer supply (Reddy et al., 1997). More than any other nutrient, nitrogen $(\mathrm{N})$ can increase or decrease yields of cotton. Yield can be drop

\footnotetext{
*Corresponding author email: milindinagro@ rediffmail.com
}

Received: 20.05.2015 
nutrient, nitrogen $(\mathrm{N})$ can increase or decrease yields of cotton. Yield can be drop sharply if apply inadequate nitrogen whereas apply nitrogen at improper time resulted slow growth of fruit, more attack of insects pests and delay in maturity. Insufficient nitrogen supply often affects the growth of cotton and developmental processes, resulting in a reduced leaf area index (LAI), low leaf chlorophyll concentration, photosynthetic rate, and biomass production (Zhao and Oosterhuis, 2000), as well as reduced lint yield and poor fibre quality (Reddy et al., 2004).

Estimation of the total chlorophyll and nitrogen contents is a potentially important aspect for both growers and researchers. Photosynthesis is an important chemical reaction in plants, and its measurement plays a critical role in agricultural production and scientific research (Wang et al., 2006). The nitrogen requirements of cotton plants vary depending on the growth rate and growth stage. Cotton leaves contain $60-85 \%$ of the total nitrogen before flowering; after flowering, the nitrogen content declines because it is translocated from the leaves to the developing bolls. A greater amount of nitrogen is required in the later growth stages when nitrogen supplies typically diminish and there is less root activity (Gerik et al., 1998).

The nutrient supplementation period can be increased with number of splits, which provides long time from square formation to boll development. Hence, nutrient requirement during critical stages can be better met with split application pattern. As such present investigation was planned to find out the response of split and foliar application of nitrogen in Bt cotton.

\section{MATERIALS AND METHODS}

The study was conducted during 2011 and 2012 in the Water Management Project, Mahatma Phule Krishi Vidyapeeth, Rahuri, Maharashtra (India) $\left(19^{\circ}-47^{\prime}\right.$ and $19^{\circ} 57^{\prime}$ North latitude and $74^{\circ}-52^{\prime}$ and $74^{\circ}-19^{\prime}$ East longitude and its mean height above sea level is 569 meter). The experiment was conducted in a randomized block design with 3 replications. The plot size was $6.3 \mathrm{~m} \times 5.4 \mathrm{~m}$. The soil of experimental plot was clay loam and slightly alkaline $(\mathrm{pH} 8.03)$, low in available nitrogen $\left(147 \mathrm{~kg} \mathrm{ha}^{-1}\right)$, medium in available phosphorus $\left(16 \mathrm{~kg} \mathrm{ha}^{1}\right)$ and high in potassium content $\left(482 \mathrm{~kg} \mathrm{ha}^{-1}\right)$. The crop was fertilized with 125: 62.50: $62.50 \mathrm{~kg}$ NPK ha ${ }^{-1}+10 \mathrm{t} \mathrm{FYM} \mathrm{ha}^{-1}$. The treatments consisted of $\mathrm{T}_{1}$ : nitrogen $(\mathrm{N})$ application in 3 equal splits at sowing, 30 and 60 Days after sowing (DAS); $\mathrm{T}_{2}: \mathrm{N}$ application in 3 splits as 20,40, 40\% at sowing, 30 and $60 \mathrm{DAS} ; \mathrm{T}_{3}: \mathrm{N}$ application in 4 equal splits at sowing, 30, 45 and $60 \mathrm{DAS} ; \mathrm{T}_{4}$ : $\mathrm{N}$ application in 5 equal splits at sowing, 30, 45, 60 and $75 \mathrm{DAS} ; \mathrm{T}_{5}: \mathrm{N}$ application in 6 splits as $20 \%$ at sowing and remaining in 5 equal splits at 30, 45, 60, 75 and $90 \mathrm{DAS} ; \mathrm{T}_{6}: \mathrm{T}_{1}+$ foliar application of $20 \mathrm{~g}$ urea litre ${ }^{-}$ ${ }^{1}$ water at 60,75 and 90 DAS; T7: $\mathrm{T}_{1}+$ foliar application of $20 \mathrm{~g} \mathrm{KNO}_{3}$ litre $^{-1}$ water at 60, 75 and $90 \mathrm{DAS} ; \mathrm{T}_{8}: \mathrm{T}_{2}+$ foliar application of $20 \mathrm{~g}$ urea litre ${ }^{-1}$ water at 60,75 and $90 \mathrm{DAS} ; \mathrm{T}_{9}: \mathrm{T}_{2}+$ foliar application of $20 \mathrm{~g} \mathrm{KNO}_{3}$ litre $^{-1}$ water at 60, 75 and 90 DAS and $\mathrm{T}_{10}$ : no nitrogen (Control). A uniform basal application of $62.50 \mathrm{~kg}$ 
phosphorus (P) through single superphosphate and $62.50 \mathrm{~kg}$ potassium $(\mathrm{K}) \mathrm{ha}^{-1}$ through murate of potash was done in all the treatments. Nitrogen was applied through urea as per the treatments. For the foliar application of nutrients at 60 DAS, 100 litres water ha ${ }^{-1}$ was used in which $2.0 \mathrm{~kg}$ urea and $\mathrm{KNO}_{3}$ as per treatments was mixed and used as spray solution. At 75 and 90 DAS, 200 litres water ha ${ }^{-1}$ along with $4.0 \mathrm{~kg}$ urea and $\mathrm{KNO}_{3}$ as per treatments was mixed and utilized as spray solution. Two seeds of cotton var. 'BG-II' (NCS 207) were sown by dibbling with $90 \mathrm{~cm} \times 45$ cm spacing on 24 April 2011 and 26 April 2012, respectively. One healthy seedling hill $^{-1}$ was maintained after thinning operation at 30 DAS. Three manual weedings were done to keep the crop free of weeds. Timely recommended plant protection measures were followed to save the crop from sucking pests (aphids, jassids, thrips and white flies) and diseases. Immediately after sowing, surface irrigation was applied to cotton crop followed by second irrigation within 1 week of sowing to ensure the good germination. Subsequent irrigations were given to the cotton crop at vegetative, square initiation, flowering, boll formation and boll-development stages during both the years. The cotton crop was harvested in 3 pickings during both the years.

For leaf nitrogen analysis fourth leaf from the top of cotton plant were collected at 60,90 and 120 DAS. Collected leaf samples were washed with distilled water for removing the dust and then dried, crushed to fine powder for estimating leaf nitrogen $(\mathrm{N})$ content using micro Kjeldahls' method, (Jackson, 1973). SPAD reading was measured with the help of chlorophyll meter SPAD- 502 Plus (Konika Minolta) from fully expanded leaf in between the leaf margin and the mid rib. The average of three SPAD values were taken as SPAD Index as the final value (Tewolde et al., 2008 and Hallikeri et al., 2011). The readings were taken at 60, 90 and 120 DAS. The leaf level photosynthesis was measured by using portable photosynthesis system LI-COR 6400 (LICOR, Inc. Lincoln, NE) at 120 DAS. The observations were recorded on the five randomly selected plants (Arriaga et al., 2009) on the red and adjacent green leaves and then averaged for per plant.

The data on various parameters recorded from experimental plot were statistically analyzed as suggested by Panse and Sukhatme (1995) by using ' $F$ ' test at $\mathrm{P}=0.05$.

\section{RESULTS AND DISCUSSION}

\section{Leaf nitrogen concentration and SPAD Index}

$\mathrm{N}$ application in 4 equal splits at sowing, 30, 45 and 60 DAS recorded significantly higher leaf $\mathrm{N}$ concentration and SPAD index at 60 DAS and it was at par with rest of the treatments except no nitrogen. At 90 and 120 DAS N application in 6 splits as $20 \%$ at sowing and remaining in 5 equal splits at 30, 45, 60, 75 and 90 DAS recorded significantly higher leaf $\mathrm{N}$ concentration and SPAD index over all other treatments except treatment $\mathrm{N}$ application in 5 equal splits at sowing, 30, 45, 60 
and 75 DAS, which was at par with $\mathrm{N}$ application in 6 splits as $20 \%$ at sowing and remaining in 5 equal splits at 30,45, 60, 75 and 90 DAS at 90 and 120 DAS. The increase in the leaf $\mathrm{N}$ concentration and SPAD value might be due to the fact that the supply of sufficient nitrogen throughout the crop growth period through split application up to 90 DAS might have helped to maintain the sufficient $\mathrm{N}$ concentration in the leaves of Bt. cotton, which led to the maintenance of the chlorophyll reflected in the higher values of SPAD index. Hallikeri et al. (2011) found that the application of nitrogen in seven splits (15 days interval) recorded higher SPAD index and leaf nitrogen concentration at 120 and 150 DAS over four splits application (30 days interval) in Bt. Cotton (Table 1 and 2).

Table 1. Leaf $\mathrm{N}$ concentration of Bt. cotton as influenced by split and foliar application of nitrogen (Pooled)

\begin{tabular}{|c|c|c|c|}
\hline \multirow{2}{*}{ Treatment } & \multicolumn{3}{|c|}{ Leaf $\mathrm{N}$ concentration $(\%)$} \\
\hline & 60 DAS & 90 DAS & 120 DAS \\
\hline $\begin{array}{l}\mathbf{T}_{1}: \mathrm{N} \text { application in } 3 \text { splits (33\% at sowing, } 33 \% \text { at } \\
30 \text { DAS and } 34 \% \text { at } 60 \text { DAS) }\end{array}$ & 1.82 & 1.63 & 1.42 \\
\hline $\begin{array}{l}\mathbf{T}_{2}: \mathrm{N} \text { application in } 3 \text { splits (20\% at sowing, } 40 \% 30 \\
\text { DAS and } 40 \% 60 \text { DAS) }\end{array}$ & 1.87 & 1.61 & 1.40 \\
\hline $\begin{array}{l}\mathbf{T}_{3}: \mathrm{N} \text { application in } 4 \text { equal splits (at sowing, 30, } 45 \\
\text { and } 60 \text { DAS) }\end{array}$ & 1.89 & 1.66 & 1.52 \\
\hline $\begin{array}{l}\mathbf{T}_{4}: \mathrm{N} \text { application in } 5 \text { equal splits (at sowing, } 30,45 \text {, } \\
60 \text { and } 75 \text { DAS) }\end{array}$ & 1.82 & 1.82 & 1.68 \\
\hline $\begin{array}{l}T_{5}: \mathrm{N} \text { application in } 6 \text { splits }(20 \% \text { at sowing and } \\
\text { remaining in } 5 \text { equal splits at } 30,45,60,75 \text { and } 90 \\
\text { DAS) }\end{array}$ & 1.82 & 1.91 & 1.77 \\
\hline $\begin{array}{l}\mathbf{T}_{6}: \mathrm{T}_{1}+\text { foliar application of } 20 \mathrm{~g} \text { urea } \text { litre }^{-1} \text { water at } \\
\quad 60,75 \text { and } 90 \text { DAS }\end{array}$ & 1.82 & 1.73 & 1.49 \\
\hline $\begin{array}{l}\mathbf{T}_{7}: \mathrm{T}_{1}+\text { foliar application of } 20 \mathrm{gNO}_{3} \text { litre }^{-1} \text { water at } \\
60,75 \text { and } 90 \text { DAS }\end{array}$ & 1.84 & 1.75 & 1.56 \\
\hline $\begin{array}{l}\mathbf{T}_{8}: \mathrm{T}_{2}+\text { foliar application of } 20 \mathrm{~g} \text { urea } \text { litre }^{-1} \text { water at } \\
60,75 \text { and } 90 \text { DAS }\end{array}$ & 1.87 & 1.70 & 1.47 \\
\hline $\begin{array}{l}\mathbf{T}_{\mathbf{9}}: \mathrm{T}_{2}+\text { foliar application of } 20 \mathrm{gNO}_{3} \text { litre }^{-1} \text { water at } \\
60,75 \text { and } 90 \text { DAS }\end{array}$ & 1.84 & 1.70 & 1.47 \\
\hline $\mathbf{T}_{\mathbf{1 0}}:$ No nitrogen & 1.56 & 1.33 & 0.89 \\
\hline $\mathrm{SEm} \pm$ & 0.02 & 0.03 & 0.05 \\
\hline $\mathrm{CD}(\mathrm{P}=0.05)$ & 0.07 & 0.09 & 0.14 \\
\hline $\mathrm{CV}(\%)$ & 3.17 & 4.37 & 7.65 \\
\hline
\end{tabular}


Table 2. SPAD Index of Bt cotton as influenced by split and foliar application of nitrogen (Pooled)

\begin{tabular}{|c|c|c|c|}
\hline \multirow{2}{*}{ Treatment } & \multicolumn{3}{|c|}{ SPAD Index } \\
\hline & 60 DAS & 90 DAS & 120 DAS \\
\hline $\begin{array}{l}\mathbf{T}_{1}: \mathrm{N} \text { application in } 3 \text { splits ( } 33 \% \text { at sowing, } \\
33 \% \text { at } 30 \text { DAS and } 34 \% \text { at } 60 \text { DAS) }\end{array}$ & 34.05 & 35.66 & 30.66 \\
\hline $\begin{array}{c}\mathbf{T}_{2}: \mathrm{N} \text { application in } 3 \text { splits (20\% at sowing, } \\
40 \% 30 \text { DAS and } 40 \% 60 \text { DAS) }\end{array}$ & 34.36 & 34.79 & 27.52 \\
\hline $\begin{array}{l}\mathbf{T}_{3}: \mathrm{N} \text { application in } 4 \text { equal splits (at sowing, } 30 \text {, } \\
45 \text { and } 60 \text { DAS) }\end{array}$ & 35.01 & 36.26 & 31.75 \\
\hline $\begin{array}{l}\mathbf{T}_{4}: \mathrm{N} \text { application in } 5 \text { equal splits (at sowing, } 30 \\
45,60 \text { and } 75 \text { DAS) }\end{array}$ & 34.19 & 39.00 & 34.40 \\
\hline $\begin{array}{l}\mathbf{T}_{5}: \mathrm{N} \text { application in } 6 \text { splits ( } 20 \% \text { at sowing and } \\
\text { remaining in } 5 \text { equal splits at } 30,45,60,75 \\
\text { and } 90 \text { DAS) }\end{array}$ & 34.07 & 39.88 & 37.62 \\
\hline $\begin{array}{l}T_{6}: T_{1}+\text { foliar application of } 20 \mathrm{~g} \text { urea } \text { litre }^{-1} \\
\text { water at } 60,75 \text { and } 90 \text { DAS }\end{array}$ & 34.15 & 36.14 & 30.68 \\
\hline $\begin{array}{l}\mathrm{T}_{7}: \mathrm{T}_{1}+\text { foliar application of } 20 \mathrm{gNO}_{3} \text { litre }^{-1} \\
\text { water at } 60,75 \text { and } 90 \text { DAS }\end{array}$ & 34.62 & 36.64 & 31.30 \\
\hline $\begin{array}{l}T_{8}: T_{2}+\text { foliar application of } 20 \mathrm{~g} \text { urea } \text { litre }^{-1} \\
\text { water at } 60,75 \text { and } 90 \text { DAS }\end{array}$ & 34.36 & 34.81 & 28.41 \\
\hline $\begin{array}{l}T_{9}: T_{2}+\text { foliar application of } 20 \mathrm{~g} \mathrm{KNO}_{3} \text { litre }^{-1} \\
\text { water at } 60,75 \text { and } 90 \text { DAS }\end{array}$ & 34.80 & 36.08 & 30.19 \\
\hline $\mathbf{T}_{\mathbf{1 0}}:$ No nitrogen & 28.83 & 27.13 & 22.28 \\
\hline $\mathrm{SEm} \pm$ & 0.42 & 0.29 & 0.32 \\
\hline $\mathrm{CD}(\mathrm{P}=0.05)$ & 1.25 & 0.87 & 0.94 \\
\hline CV (\%) & 3.04 & 2.01 & 2.55 \\
\hline
\end{tabular}

\section{Photosynthesis}

The leaf level photosynthesis of healthy leaf was significantly influenced by various treatments at 120 DAS (Figure 1 and Table 3). Nitrogen application in 6 splits as $20 \%$ at sowing and remaining in 5 equal splits at 30, 45, 60, 75 and 90 DAS recorded significantly higher photosynthesis in healthy leaves $\left(15.47 \mu \mathrm{mol} \mathrm{CO} \mathrm{CO}^{-2} \mathrm{~s}^{-}\right.$ ${ }^{1}$ ) over all other treatments except $\mathrm{N}$ application in 4 equal splits at sowing, 30, 45 
and 60 DAS (13.95 $\left.\mu \mathrm{mol} \mathrm{CO} \mathrm{CO}^{-2} \mathrm{~s}^{-1}\right), \mathrm{N}$ application in 5 equal splits at sowing, 30, 45, 60 and 75 DAS $\left(15.07 \mu \mathrm{mol} \mathrm{CO} \mathrm{Cm}^{-2} \mathrm{~s}^{-1}\right)$ and $\mathrm{N}$ application in 3 splits as 20, 40, $40 \%$ at sowing, 30 and 60 DAS + foliar application of $20 \mathrm{~g}$ urea litre $^{-1}$ water at 60,75 and 90 DAS $\left(14.27 \mu \mathrm{mol} \mathrm{CO} \mathrm{m}^{-2} \mathrm{~s}^{-1}\right)$ which were at par with nitrogen application in 6 splits as $20 \%$ at sowing and remaining in 5 equal splits at 30, 45, 60, 75 and 90 DAS. Nitrogen application in 6 splits as $20 \%$ at sowing and remaining in 5 equal splits at 30, 45, 60, 75 and 90 DAS recorded significantly higher photosynthesis (2.46 $\mu \mathrm{mol} \mathrm{CO}_{2} \mathrm{~m}^{-2} \mathrm{~s}^{-1}$ ) in red leaf also. The mean rate of photosynthesis in healthy leaf was higher by $988 \%$ than the mean net photosynthesis (Pn) in red leaf. The premature photosynthetic decline of the cotton canopy due to an apparent remobilization of ribulose 1,5 biphosphate carboxylase- oxydase (Rubisco) to support the strong developing reproductive sink demand (Pettigrew et al., 2000) suggests that extra and timely $\mathrm{N}$ fertilization could maintain the canopy's photosynthetic capacity longer and potentially support even greater yield increases. Dhopte and Zade (1980) also reported the remarkable drop in the rate of photosynthesis in red leaf of cotton.

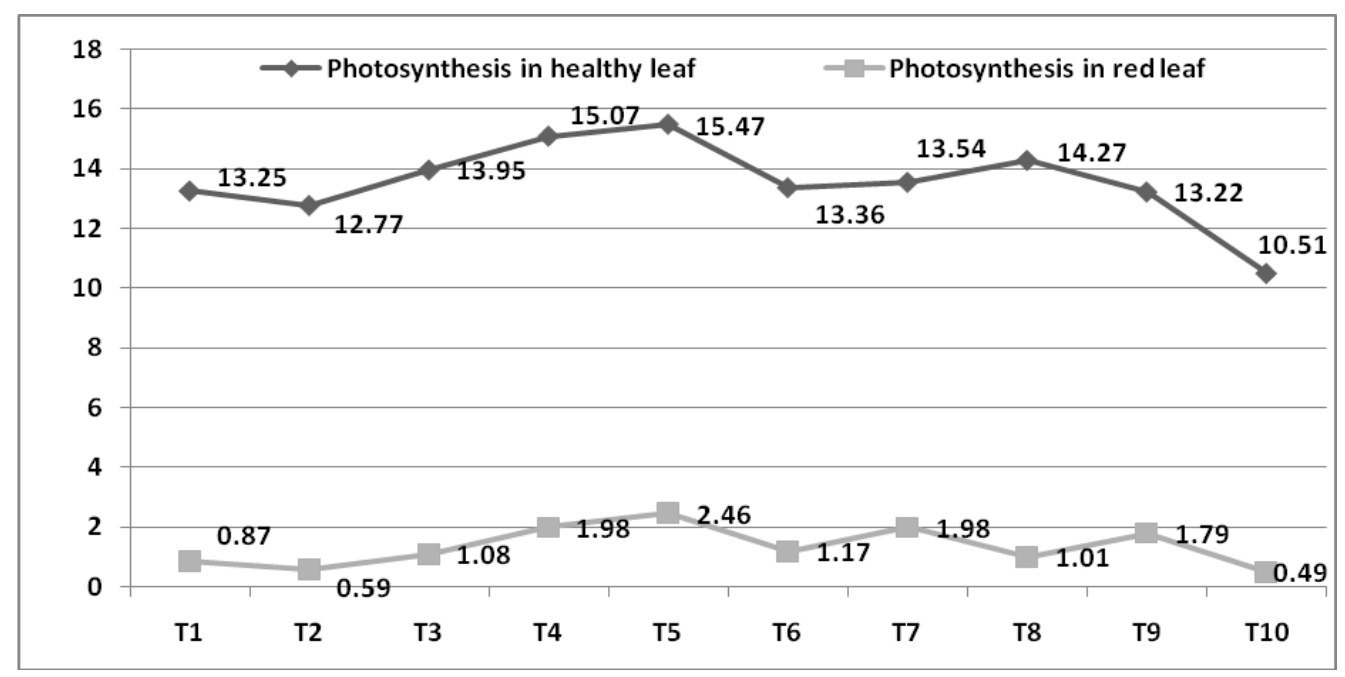

Figure 1. Rate of photosynthesis $\left(\mu \mathrm{mol} \mathrm{CO} \mathrm{Cm}^{-2} \mathrm{~s}^{-1}\right)$ in healthy and red leaf of Bt. Cotton as influenced by split and foliar application of nitrogen (Pooled) 
Table 3. Rate of photosynthesis $\left(\mu \mathrm{mol} \mathrm{CO} \mathrm{CO}^{-2} \mathrm{~s}^{-1}\right)$ in healthy and red leaf of Bt. Cotton as influenced by split and foliar application of nitrogen (Pooled)

\begin{tabular}{|c|c|c|}
\hline \multirow[t]{2}{*}{ Treatment } & \multicolumn{2}{|c|}{$\begin{array}{l}\text { Rate of photosynthesis ( } \mu \text { mo } \\
\quad \mathrm{CO}_{2} \mathrm{~m}^{-2} \mathrm{~s}^{-1} \text { ) at } 120 \text { DAS }\end{array}$} \\
\hline & Healthy leaf & Red leaf \\
\hline $\begin{array}{l}\mathbf{T}_{1}: \mathrm{N} \text { application in } 3 \text { splits ( } 33 \% \text { at sowing, } 33 \% \text { at } 30 \\
\text { DAS and } 34 \% \text { at } 60 \text { DAS) }\end{array}$ & 13.25 & 0.87 \\
\hline $\begin{array}{l}\mathbf{T}_{2}: \mathrm{N} \text { application in } 3 \text { splits (20\% at sowing, } 40 \% 30 \text { DAS } \\
\text { and } 40 \% 60 \text { DAS) }\end{array}$ & 12.77 & 0.59 \\
\hline $\begin{array}{l}\mathbf{T}_{3}: \mathrm{N} \text { application in } 4 \text { equal splits (at sowing, } 30,45 \text { and } 60 \\
\text { DAS) }\end{array}$ & 13.95 & 1.08 \\
\hline $\begin{array}{l}\mathbf{T}_{4}: \mathrm{N} \text { application in } 5 \text { equal splits (at sowing, } 30,45,60 \text { and } \\
75 \text { DAS) }\end{array}$ & 15.07 & 1.98 \\
\hline $\begin{array}{l}\mathbf{T}_{5}: \mathrm{N} \text { application in } 6 \text { splits ( } 20 \% \text { at sowing and remaining in } \\
5 \text { equal splits at } 30,45,60,75 \text { and } 90 \text { DAS) }\end{array}$ & 15.47 & 2.46 \\
\hline $\begin{array}{l}\mathbf{T}_{\mathbf{6}}: \mathrm{T}_{1}+\text { foliar application of } 20 \mathrm{~g} \text { urea } \text { litre }^{-1} \text { water at } 60,75 \\
\text { and } 90 \text { DAS }\end{array}$ & 13.36 & 1.17 \\
\hline $\begin{array}{l}\mathbf{T}_{7}: \mathrm{T}_{1}+\text { foliar application of } 20 \mathrm{~g} \mathrm{KNO}_{3} \text { litre }^{-1} \text { water at } 60 \text {, } \\
75 \text { and } 90 \text { DAS }\end{array}$ & 13.54 & 1.98 \\
\hline $\begin{array}{l}\mathbf{T}_{\mathbf{8}}: \mathrm{T}_{2}+\text { foliar application of } 20 \mathrm{~g} \text { urea litre }{ }^{-1} \text { water at } 60,75 \\
\text { and } 90 \text { DAS }\end{array}$ & 14.27 & 1.01 \\
\hline $\begin{array}{l}\mathbf{T}_{9}: \mathrm{T}_{2}+\text { foliar application of } 20 \mathrm{~g} \mathrm{KNO}_{3} \text { litre }^{-1} \text { water at } 60 \text {, } \\
75 \text { and } 90 \text { DAS }\end{array}$ & 13.22 & 1.79 \\
\hline $\mathbf{T}_{\mathbf{1 0}}:$ No nitrogen & 10.51 & 0.49 \\
\hline $\mathrm{SEm} \pm$ & 0.60 & 0.04 \\
\hline $\mathrm{CD}(\mathrm{P}=0.05)$ & 1.78 & 0.12 \\
\hline $\mathrm{CV}(\%)$ & 10.83 & 7.48 \\
\hline
\end{tabular}

\section{Yield contributing parameters and lint yield}

Data regarding yield contributing parameters (plant height, dry matter accumulation, No. of bolls palnt ${ }^{-1}$, boll weight and ginning outturn) lint (g) plant ${ }^{-1}$ and lint yield $\left(\mathrm{kg} \mathrm{ha}^{-1}\right)$ as influenced by various treatments on inceptisol are presented in table 4. 
Split and foliar application of nitrogen significantly influenced the cotton plant height, bolls plant ${ }^{-1}$, dry-matter accumulation, seed cotton yield plant ${ }^{-1}$ and boll weight. Application of nitrogen in 6 splits (20\% at sowing and remaining in 5 equal splits at 30, 45, 60, 75 and 90 DAS) recorded significantly higher plant height, bolls plant $^{-1}$, dry-matter accumulation and seed-cotton yield plant ${ }^{-1}$ compared to the other treatments. Nitrogen plays an important role in multiplication of cells and formation of plant parts, which resulted in higher growth of cotton. Cotton being an indeterminate crop having long duration, timely supply of nitrogen under split application might have increased bolls, dry matter accumulation plant ${ }^{-1}$, which resulted in higher seed-cotton yield plant ${ }^{-1}$. Split application of nitrogen encourages more dry-matter accumulation and finally resulted into better yield (Srinivasan, 2003). Application of nitrogen at 0, 30, 45, 60, 75 and 90 DAS might have been congenial to meet the peak nitrogen requirement of Bt. Cotton crop. The effect of various treatments on ginning out turn was found to be non significant. This can be attributed to the fact that the quality parameter viz., ginning outturn $(\%)$ is genetically governed and in general agronomic practices have very less impact on these genetically governed parameters. Therefore in the present investigation the effect of various treatments on this parameter was found to be non- significant. The important yield component boll weight was significantly influenced by foliar nutrition. Nitrogen application in 3 equal splits at sowing, 30 and 60 DAS + foliar application of $20 \mathrm{~g} \mathrm{KNO}_{3}$ litre $^{-1}$ water at 60,75 and 90 DAS recorded significantly higher boll weight over rest of the treatments except treatment $T_{9}$ which was on a par with $T_{7}$. This could be attributed to the role of nitrogen $(\mathrm{N})$ and potassium $(\mathrm{K})$. The positive effect of mineral nutrients supplied through $\mathrm{KNO}_{3}$ on a number of sink organs results not only from an increase in mineral nutrient supply, but also an increase in the photosynthate supply to the sink sites (Borowski, 2001). Increase in boll weight with foliar application of $\mathrm{KNO}_{3}$ is in agreement with results of Reddy et al. (2004) and Read et al. (2006).

Nitrogen $(\mathrm{N})$ application in 6 splits as $20 \%$ at sowing and remaining in 5 equal splits at 30, 45, 60, 75 and 90 DAS recorded significantly higher lint yield $\left(\mathrm{kg} \mathrm{ha}^{-1}\right)$ over all other treatments. The best treatment $\left(\mathrm{T}_{5}\right)$ recorded 35 and $47 \%$ more lint yield than the recommended practices $\left(\mathrm{T}_{1}\right.$ and $\mathrm{T}_{2}$, respectively) whereas the same treatment recorded $200 \%$ more lint yield over the treatment no nitrogen $\left(\mathrm{T}_{10}\right)$. The lowest lint yield $\left(\mathrm{kg} \mathrm{ha}^{-1}\right)$ was observed with the treatment no nitrogen. It could be attributed to the improvement of physiological parameters viz., higher chlorophyll and nitrogen content in the leaf, higher photosynthetic rate of the leaf observed with the treatment nitrogen application in 6 splits as $20 \%$ at sowing and remaining in 5 equal splits at 30, 45, 60, 75 and 90 DAS, which cumulatively resulted in higher lint yield $\left(\mathrm{kg} \mathrm{ha}^{-1}\right)$. Gawade and Bhalerao (2012) observed the significantly higher seed cotton yield with the application of nitrogen in six splits. Similar observation was made by However, Hosmath et al. (2012) that higher seed cotton yield with the application of nitrogen in six splits along with foliar application of $2 \% \mathrm{KNO}_{3}$ in $B t$ cotton. 
Table 4. Plant height, dry matter accumulation, number of bolls plant ${ }^{-1}$, boll weight, ginning outturn and lint yield of Bt. cotton as influenced by split and foliar application of nitrogen (Pooled)

\begin{tabular}{|c|c|c|c|c|c|c|c|}
\hline Treatment & $\begin{array}{l}\text { Plant } \\
\text { height } \\
(\mathrm{cm})\end{array}$ & $\begin{array}{c}\text { Dry } \\
\text { matter } \\
\left(\mathrm{g}_{1}^{1}\right)\end{array}$ & $\begin{array}{l}\text { No. of } \\
\text { bolls } \\
\text { plant }^{-1}\end{array}$ & $\begin{array}{c}\text { Boll } \\
\text { weight }(\mathrm{g} \\
\left.\text { boll }^{-1}\right)\end{array}$ & $\begin{array}{l}\text { Ginning } \\
\text { outturn } \\
(\%)\end{array}$ & $\begin{array}{c}\text { Lint } \\
\text { yield } \\
\left(\mathrm{g} \mathrm{plant-}_{1}\right)\end{array}$ & $\begin{array}{l}\text { Lint } \\
\text { yield }(\mathrm{kg} \\
\left.\text { ha- }^{1}\right)\end{array}$ \\
\hline $\begin{array}{l}\mathbf{T}_{\mathbf{1}}: \mathrm{N} \text { application in } 3 \text { splits } \\
(33 \% \text { at sowing, } 33 \% \text { at } \\
\text { 30 DAS and } 34 \% \text { at } 60 \\
\text { DAS) }\end{array}$ & 95.03 & 177.88 & 22.83 & 4.26 & 35.15 & 34.15 & 788.73 \\
\hline $\begin{array}{c}\mathbf{T}_{2}: \mathrm{N} \text { application in } 3 \text { splits } \\
\text { (20\% at sowing, } 40 \% 30 \\
\text { DAS and } 40 \% \text { 60 DAS) }\end{array}$ & 95.02 & 175.27 & 21.90 & 4.28 & 35.22 & 32.38 & 725.15 \\
\hline $\begin{aligned} \mathbf{T}_{3}: & \mathrm{N} \text { application in } 4 \text { equal } \\
& \text { splits (at sowing, 30, } 45 \\
& \text { and } 60 \text { DAS) }\end{aligned}$ & 102.20 & 188.17 & 29.53 & 4.28 & 35.29 & 43.84 & 911.04 \\
\hline $\begin{array}{l}\mathbf{T}_{\mathbf{4}}: \mathrm{N} \text { application in } 5 \text { equal } \\
\text { splits (at sowing, 30, 45, } \\
60 \text { and } 75 \text { DAS) }\end{array}$ & 105.17 & 188.63 & 30.93 & 4.29 & 35.38 & 46.40 & 974.86 \\
\hline $\begin{aligned} & \mathbf{T}_{5}: \mathrm{N} \text { application in } 6 \text { splits } \\
&(20 \% \text { at sowing and } \\
& \text { remaining in } 5 \text { equal } \\
& \text { splits at } 30,45,60,75 \\
&\text { and } 90 \text { DAS })\end{aligned}$ & 114.66 & 200.64 & 37.13 & 4.34 & 35.47 & 57.00 & 1069.36 \\
\hline $\begin{array}{c}\mathbf{T}_{\mathbf{6}}: \mathrm{T}_{1}+\text { foliar application } \\
\text { of } 20 \mathrm{~g} \text { urea litre }{ }^{-1} \text { water } \\
\text { at } 60,75 \text { and } 90 \mathrm{DAS}\end{array}$ & 98.89 & 182.03 & 23.83 & 4.28 & 35.31 & 35.62 & 896.41 \\
\hline $\begin{array}{l}\mathbf{T}_{7}: \mathrm{T}_{1}+\text { foliar application } \\
\text { of } 20 \mathrm{~g} \mathrm{KNO}_{3} \text { litre }{ }^{-1} \\
\text { water at } 60,75 \text { and } 90 \\
\text { DAS }\end{array}$ & 100.56 & 187.60 & 26.17 & 4.51 & 35.31 & 41.60 & 908.59 \\
\hline $\begin{array}{c}\mathbf{T}_{\mathbf{8}}: \mathrm{T}_{2}+\text { foliar application } \\
\text { of } 20 \mathrm{~g} \text { urea litre }{ }^{-1} \text { water } \\
\text { at } 60,75 \text { and } 90 \mathrm{DAS}\end{array}$ & 98.60 & 181.71 & 22.60 & 4.31 & 35.28 & 34.06 & 774.48 \\
\hline $\begin{array}{l}\mathbf{T}_{\mathbf{9}}: \mathrm{T}_{2}+\text { foliar application } \\
\text { of } 20 \mathrm{~g} \mathrm{KNO}_{3} \text { litre } \\
\text { water at } 60,75 \text { and } 90 \\
\text { DAS }\end{array}$ & 100.76 & 183.24 & 23.83 & 4.46 & 35.37 & 36.95 & 898.89 \\
\hline $\mathbf{T}_{10}:$ No nitrogen & 64.77 & 112.98 & 15.57 & 3.28 & 34.98 & 19.53 & 357.17 \\
\hline S.E. $(\mathrm{m}) \pm$ & 2.38 & 3.14 & 0.79 & 0.03 & 0.11 & 1.30 & 28.61 \\
\hline $\mathrm{CD}(\mathrm{P}=0.05)$ & 7.06 & 9.34 & 2.35 & 0.10 & NS & 3.86 & 85.01 \\
\hline $\mathrm{CV}(\%)$ & 5.97 & 4.33 & 7.62 & 2.02 & 0.76 & 8.05 & 8.22 \\
\hline
\end{tabular}




\section{CONCLUSION}

The result showed that splits application as $20 \%$ days after sowing (DAS) and remaining 5 splits at 30, 45, 60, 60, 75 and 90 DAS resulted higher lint yield and yield attributes of cotton as well as improvement physiological parameters.

\section{REFERENCES}

Anonymous. 2012. All India Coordinated Cotton Improvement Project, Annual Report, 2011-2012

Arriaga, F. J., Prior, S. A., Terra, J. F. and Delaney, D. P. 2009. Cotton gas exchange response to standard and ultra-narrow row systems under conventional and no-tillage. Communications in Biometry and Crop Science, 4(2): 42-51

Borowski, E. 2001. The effect of nitrogenous compounds on the growth, photosynthesis and phosphorus uptake of sunflower. Annales Universitaties Marie Curie- Sklodowska. Sectio EEE, Horticultura, 9: 23-31

Chandrashekara, C. P., Hallikeri, S. S., Nandagavi, R. A., Aladakatti, Y. R., Vamadevaiah, H. M. and Patil, B. C. 2012. Management of leaf reddening through integrated and foliar nutrition approach in Bt cotton. Extended summaries, Vol. 2: $3^{\text {rd }}$ International Agronomy Congress, Nov. 26-30, 2012, New Delhi, India: 391-392

Dhopte, A. M. and Zade, V. C. 1980. Comparative Physiological studies of arboretum and hirsutum cottons in relation to leaf reddening. Science and culture, 46 2: 62

Gawade, R. T. and Bhalerao, P. D. 2012. Effect of fertilizer application on leaf reddening and yield of Bt cotton. Bioinfolet, 9 (3): 382-384

Gerik, J. T., Oosterhuis, D. M. and Torbert, H. A. 1998. Managing Cotton Nitrogen Supply. In: "Advances in Agronomy", (Ed.): Sparks, D. L. Academic press, San Diego, CA

Hallikeri, S. S., Halemani, H. L., Patil, B. C. and Nandagavi, R. A. 2011. Influence of nitrogen management on expression of cry protein in Bt cotton (Gossypium hirsutum). Indian Journal of Agronomy, 56 (1): 62-67

Hebber, K. B., Perumal, N. K. and Khadi, B. M. 2007. Photosynthesis and plant growth response of transgenic Bt cotton (Goyssypium hirsutum L.) hybrids under field condition. Photosynthetica, 45(2): 254-258

Hosmath, J. A., Biradar, D. P., Patil, V. C. and Malligawad, L. H. 2012. Assessing the effect of temperature on leaf reddening in Bt cotton. Extended summaries Vol. 2: $3^{\text {rd }}$ international Agronomy Congress, Nov. 26-30, New Delhi, India: 32-34

Jackson, M. L. 1973. Soil Chemical Analysis. Prentice Hall of India Pvt. Ltd., New Delhi

Pettigrew, W. T., Heitholt, J. J. and Vaughn, K. C. 2000. Leaf senescence- like characteristics contribute to cotton's premature photosynthetic decline. Photosynthetc Research, 65: 187-195 
Read, J. J., Reddy, K. R. and Jenkins, J. N. 2006. Yield and fibre quality of upland cotton as influenced by nitrogen and potassium nutrition. European Journal of Agronomy, 24(3): 282-290

Reddy, K. R., Hodges, H. F. and McKinion, J. M. 1997. Crop modeling and applications: A cotton example. Advances in Agronomy, 59: 225-290

Reddy, K. R., Koti, S., Davidonis, G. H. and Reddy, V. R. 2004. Interactive effects of carbon dioxide and nitrogen nutrition on cotton growth, development, yield, and fiber quality. Agronomy Journal, 96: 1148-1157

Singh, J., Blaise, D., Rao, M. R. K., Mayee, C. D. and Deshmukh, M. S. 2003. Assessment of agronomic efficiency of Bt cotton in rainfed vertisol. Journal of Indian Society of Cotton Improvement, 28: 185-190

Srinivasan, G. 2003. Response of cotton (Gossypium hirsutum) to split application of major nutrients. Indian Journal of Agronomy, 48(1): 59-61

Tewolde, H., Shankle, M. W., Sistani, A. and Rowe, D. E. 2008. No- till and conservational till cotton response to broiler litter fertilization in upland soil: lint yield. Agronomy Journal, 100 (3): 503-509

Wang, J., Xing, D. and Xu, W. 2006. Development of a Portable Photosynthesis Rate Measurement Device. Proc. SPIE 6047, Fourth International Conference on Photonics and Imaging in Biology and Medicine, 60473W (October 27, 2006) Tianjin, China

Zhao, D. and Oosterhuis, D. M. 2000. Nitrogen application effect on leaf photosynthesis, nonstructural carbohydrate concentrations and yield of field-grown cotton. In D.M. Oosterhuis (Ed.), Proceedings of the 2000 Arkansas Cotton Research Meeting. AAES Special Report, 198: 69-71 